\title{
TRICHODESMIUM ERYTHRAEUM BLOOM ON THE CONTINENTAL SHELF OFF SANTOS, SOUTHEAST BRAZIL
}

\author{
Melissa Carvalho ${ }^{1}$, Sônia M. F. Gianesella and Flávia M. P. Saldanha-Corrêa
}

Instituto Oceanográfico da Universidade de São Paulo

(Praça do Oceanográfico, 191, 05508-120 São Paulo, SP, Brasil)

${ }^{1}$ melissa@io.usp.br

The Trichodesmium erythraeum is a common colonial marine cyanobacterium in tropical and subtropical oceans. Several authors have reported its importance for the fixation of both atmospheric $\mathrm{C}$ and N (CAPONE; CARPENTER, 1982; ZEHR et al., 2001; LUGOMELA et al., 2002; CAPONE et al., 2005). According to Carpenter and Romans (1991), nitrogen fixation by Trichodesmium cells represents an important input of new nitrogen into the euphotic zone, with daily fixation rates of approximately $30 \mathrm{mg}^{-}$ ${ }^{1} \mathrm{~N} \mathrm{~m}^{-2} \mathrm{~d}^{-1}$. This exceeds the estimated flux of nitrate across the thermocline. Capone and Carpenter (1982) reported the total annual nitrogen fixation by Trichodesmium sp as $4.810^{12} \mathrm{~g} \mathrm{~N} \mathrm{y}^{-1}$ in the world's oceans, corresponding to $1 / 5$ of the $\mathrm{N}$ fixation in all terrestrial environments. Besides fixing nitrogen, Trichodesmium cells are able to maintain their phosphorus requirement through the production of alkaline phosphatases, enzymes which enable the organism to remove the inorganic phosphate radical from organically bound phosphate (YENTSCH et al., 1972). Hahn and Capra (1992) have demonstrated the ability of $T$. erythraeum (Oscillatoria erythraea) to synthesize a ciguatoxin-like compound. Other studies (FONSECA et al., 2002, unpublished; NEGRI et al., 2004) report the presence of $T$. erythraeum in the environment with harmful effects on the components of the marine biota.

Here we report the occurrence of a $T$. erythraeum bloom off the southeastern Brazilian coast (Fig. 1). A superficial brownish patch was detected visually (Fig. 2) during an oceanographic cruise from March 23-26, 2006 on the continental shelf off Santos.

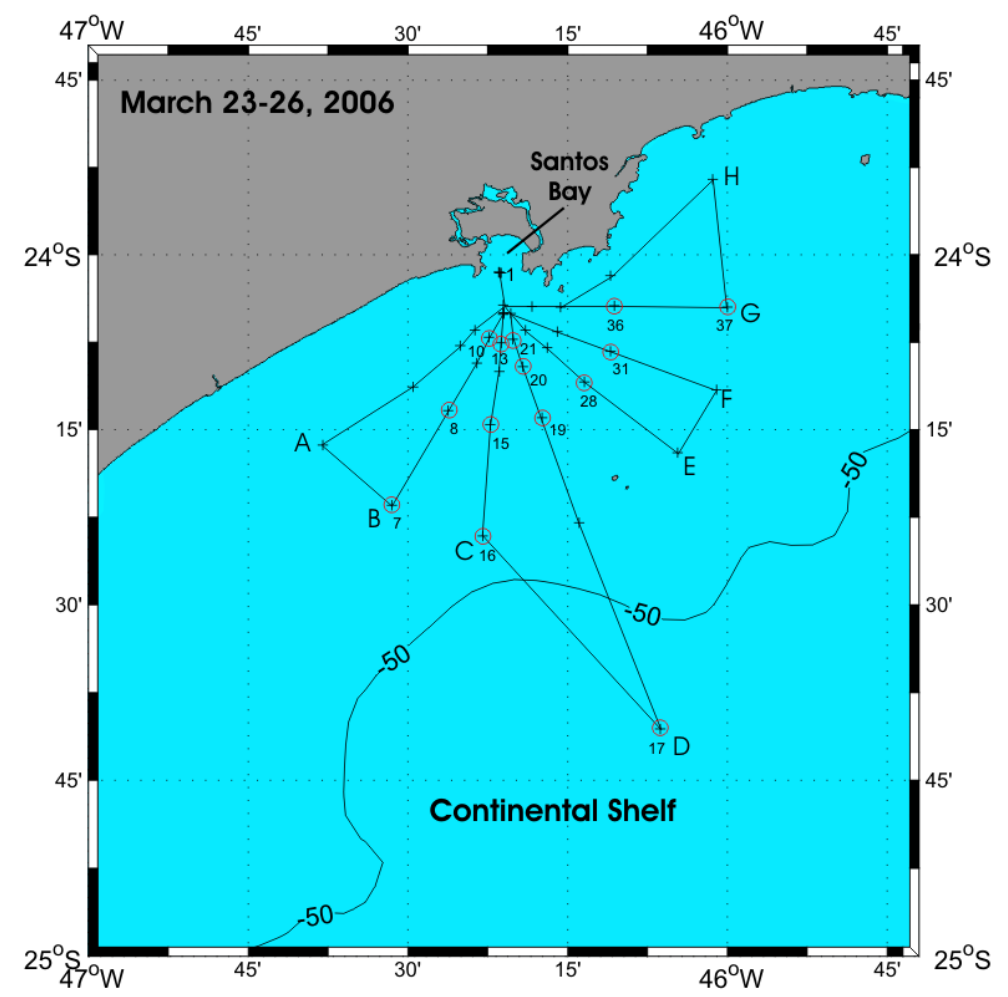

Fig. 1. Study area on the continental shelf off Santos, showing the distribution of the oceanographic stations visited in March 2006. Stations of bloom occurrence are indicated by circles. 


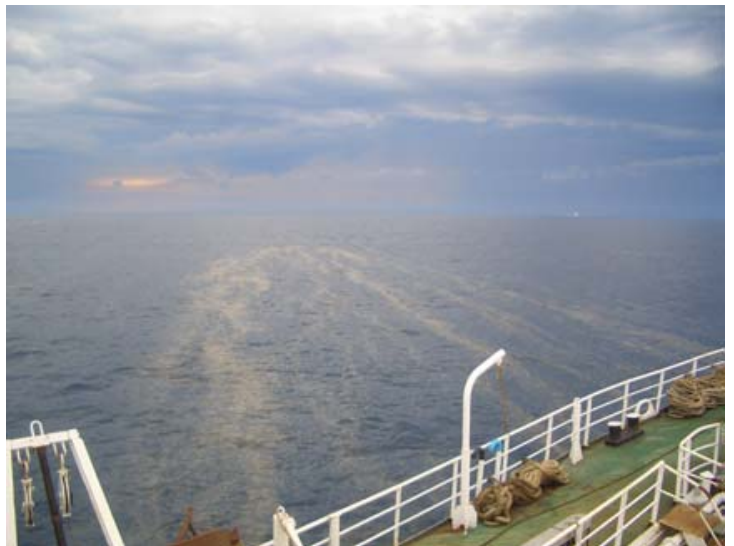
(a) Photo:P. Andrade

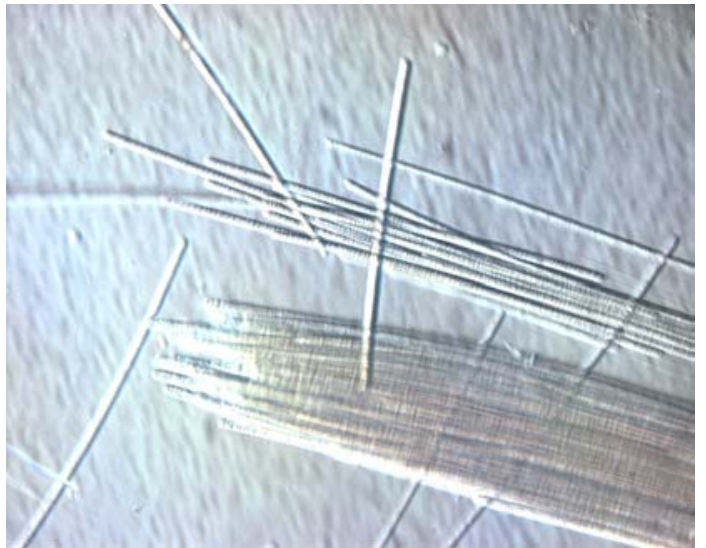

(b) Photo: M. Carvalho

Fig. 2. a) Surface patches of Trichodesmium erythraeum visible to the naked eye, on the continental shelf off Santos. b) Bundle of $T$. erythraeum with parallel trichomes.

Samplings were undertaken on the basis of a grid of 40 oceanographic stations distributed along eight sections with the same point of origin: in the middle portion of the mouth of Santos Bay (Fig. 1). Surface water samples were collected using a Niskin bottle. The water samples were filtered through AP-40 Millipore filters for chlorophyll- $a$ (Chl-a) determination (SALDANHA-CORRÊA et al., 2004). However, it is relevant to note that these brownish colored patches are mainly neustonic. Therefore, the sampling procedure used for Chl- $a$ determination certainly underestimated the $T$. erythraeum biomass. The filtered water was used for dissolved inorganic nutrient determination (nitrate, nitrite, ammonium and phosphate). Temperature, salinity and Chl-a fluorescence were profiled using a CTD Falmouth, equipped with a fluoremeter. The euphotic zone depth was determined based on Secchi disc readings (POOLE; ATKINS, 1929). Net plankton samples were obtained by vertical tows ( $30 \mu \mathrm{m}$ mesh) at the 33 oceanographic stations distributed along the sections (the exception was the station in the entrance of the Santos Bay). Chl- $a$ concentration was determined by spectrophotometry in accordance with Jeffrey and Humphrey (1975). Nitrate, nitrite and ammonium were determined in accordance with Aminot and Chaussepied (1983). Phosphate was determined following Grasshoff et al. (1983).

The relative abundance of $T$. erythraeum was evaluated in order to determine the bloom's extension and the relative importance of this species to the bulk microphytoplankton biomass along the water column. Microplankton counts were undertaken in hemocytometer chambers (Nageotte, sample volume of $0.625 \mathrm{~mm}^{3}$ ) under a light optical microscope (Zeiss, 400x magnification). The cells were counted individually except for $T$. erythraeum, regarding which the number of filaments was considered. A minimum of 400 cells were counted per chamber. When $T$. erythraeum bundles were observed an estimate of the number of filaments per bundle was made. According to Smayda (1997), the definition of a bloom is subjective. Thus the following criterion was applied: when the relative frequency of $T$. erythraeum filaments represented more than $50 \%$ of the total cell number present in the sample, the sampling station was considered to be inside the bloom. As a result, the bloom enclosed 14 stations in the central region of the study area (Fig. 1), with an estimated extension of about $1100 \mathrm{~km}^{2}$. The greatest abundance of $T$. erythraeum was $113.210^{6}$ filaments $\mathrm{L}^{-1}(99 \%$ of the total cell number) observed at station 19 (Fig. 2b), approximately in the center of the bloom area $\left(46^{\circ} 17.4^{\prime} \mathrm{W}\right.$ and $\left.26^{\circ} 14^{\prime} \mathrm{S}\right)$. Samples taken from the bloom area presented a large number of the dinoflagellate Ceratium sp and copepods. Carpenter (1983) in a review of the physiology and ecology of the Trichodesmium genus, states that some organisms, such as copepods, bacteria, diatoms, hydrozoans and even fungi, can be associated with this genus, especially when bundles are present.

Several authors affirm that atmospheric and calm sea conditions are essential for the development of Trichodesmium blooms (LEWIS et al., 1988; GIANESELLA-GALVÃO et al., 1995; SARANGI et al., 2004, SIQUEIRA et al., 2006). The calm weather observed during the bloom and the absence of winds corroborate Bryceson and Fay's (1981) and Carpenter's (1983) 
hypothesis regarding bloom formation. According to them the action of winds can disrupt the organization of the bundles. The organization of filaments in bundles or mats is ecologically important as the $\mathrm{N}_{2}$ fixation occurs in their central part where nitrogenase is protected from $\mathrm{O}_{2}$ inactivation (CARPENTER; PRICE, 1976).

During the first three days of sampling, the weather conditions remained stable, with weak to moderate winds. The water surface was smooth, and the sky cloudy with intense diffuse solar radiation. On the fourth day of sampling, a cold front traversed the area (CPTEC, 2006), making the sea rough, but the bloom still remained. Such blooms can persist for several days, as reported by Gianesella-Galvão et al. (1995) who followed a bloom with a width of about 30 $\mathrm{km}$ for 17 days off Ubatuba (about $150 \mathrm{~km}$ North of Santos), with steady weather and a calm sea, during the summer of 1990. Tyrrel et al. (2003), working on the Atlantic between the Falkland Islands $\left(50^{\circ} \mathrm{S}\right)$ and the UK $\left(50^{\circ} \mathrm{N}\right)$, observed a great abundance of Trichodesmium, correlated with shallow mixed layer depth, a condition similar to that observed on the Santos shelf.

In the present study, the sea surface temperatures ranged between 27 and $29^{\circ} \mathrm{C}$ and the salinity varied from 33.1 to 35.2 . The water column was strongly stratified (Fig. 3), with a mixture of Tropical Water mass (TW) and Coastal Water (CW) predominating in the mixed layer, whereas the South Atlantic Central Water (SACW) was detected in the bottom layers, below 20m depth, according to the water mass classification proposed by Miranda (1982, unpublished)). TW is recognized by its low nutrient content (AIDAR et al., 1993). Indeed, nutrient concentrations were low, with higher concentrations in the Santos inlet station, due the influence of the eutrophic bay waters. Surface waters presented a mean concentration of $0.33 \mu \mathrm{M}$ for dissolved inorganic nitrogen (DIN) and $0.29 \mu \mathrm{M}$ for inorganic phosphate. Considering only the bloom stations, the mean concentrations decrease to $0.18 \mu \mathrm{M}$ of DIN and 0.19 $\mu \mathrm{M}$ of phosphate. Moreover, at station 19, where the highest $T$. erythraeum density was attained, the DIN concentration was $0.07 \mu \mathrm{M}$ whereas phosphate was below the detection limit of the analysis. These data corroborate the fact already verified by other authors (CAPONE; CARPENTER, 1982; CARPENTER, 1983) that inorganic nutrients are not limiting factors for the development of the T. erythraeum bloom, which can be controlled by other biological, chemical or physical factors. Carpenter (1983) points out that Trichodesmium growth is not stimulated in classical upwelling areas. On the contrary, it may be inhibited. According to this latter author, waters containing the critical elements for nitrogenase synthesis or organic phosphorous compounds can favor the bloom formation. The lower nutrient concentration observed in the bloom regions can be ascribed to the ability of T. erythraeum to obtain $\mathrm{N}$ and $\mathrm{P}$ from sources beyond the inorganic compounds dissolved in the water.

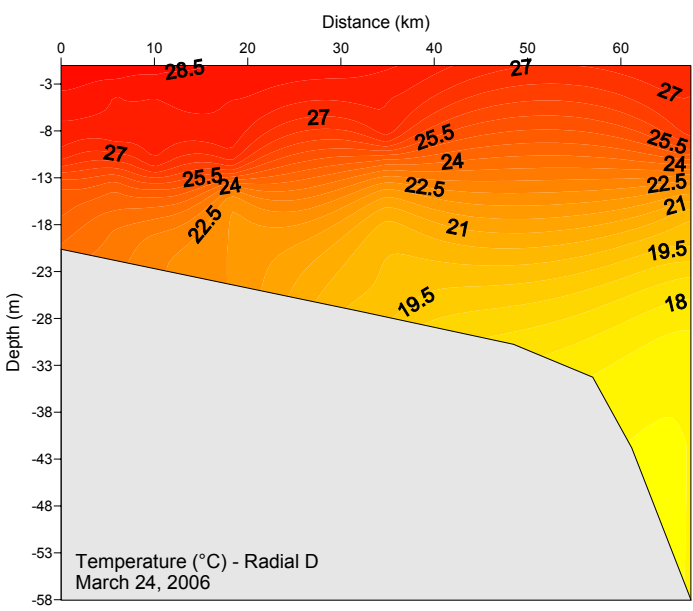

(a)

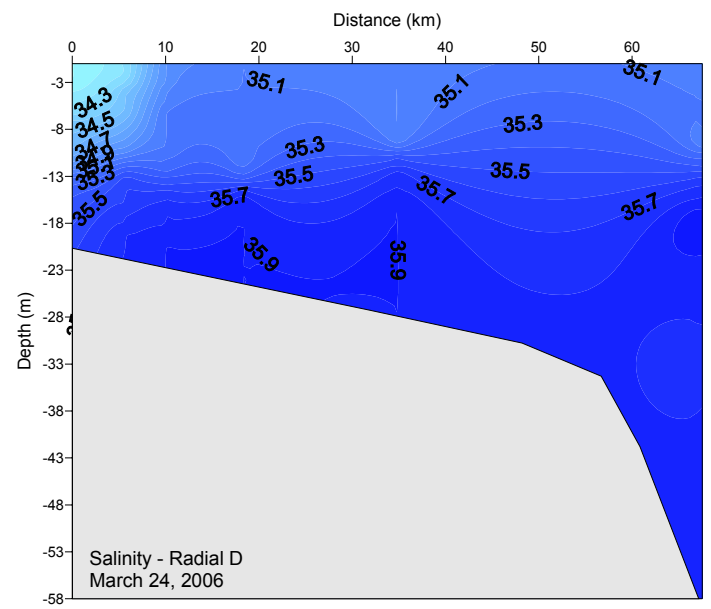

(b)

Fig. 3. Vertical profiles of temperature $\left({ }^{\circ} \mathrm{C}\right)(\mathrm{a})$ and salinity (b) on the radial D, on March 24, 2006. 
The maximum concentration of Chl-a (14.5 $\mathrm{mg} \mathrm{\textrm {m } ^ { - 3 }}$ ) was detected at station 1 , in the entrance of Santos Bay. T. erythraeum was not present at that site. A low Chl- $a$ concentration was observed in the bloom area, reflecting the oligotrophic condition of the water. However, the Trichodesmium biomass was not adequately estimated in the surface waters due to the sampling method used, even though bottles, nets or buckets are the usual sampling apparatus. In effect, Tyrrell et al. (2003) compared these different types of sampling apparatus and ascertained that they agreed well qualitatively. But we believe that a neustonic sampler apparatus would probably have provided more accurate results, particularly for the Trichodesmium biomass since the traditional sampling techniques disrupt the surface algae pellicle formed by the bloom, thus hindering efficient sampling. Unfortunately a neustonic sampler was not available on board, so this technique could not be tested. Consequently, Chl- $a$ is more closely related to the bulk of the phytoplankton biomass present in the superficial layers than to the neustonic T. erythraeum biomass. Conspicuous deep chlorophyll maxima at the thermocline base were also detected by the fluorescence profiles, but Trichodesmium was not observed in such formations. Recent studies (LEVITAN et al., 2007; HUTCHINS et al., 2007) have suggested that the increase of $\mathrm{pCO}_{2}$ foreseen for the end of this century, which will perhaps attain $150 \%$ or more of the current values, may increase global Trichodesmium $\mathrm{N}_{2}$ and $\mathrm{CO}_{2}$ fixation substantially, thus fundamentally altering the current marine $\mathrm{N}$ and $\mathrm{C}$ cycles and potentially driving some oceanic regimes (mainly at central gyres) towards P limitation, implying shifts in the structure of microbial and metazoan communities. Hutchins (2008) proposes that the growth and $\mathrm{N}_{2}$ fixation by this biogeochemically critical genus is carbon limited by the current levels of $\mathrm{pCO}_{2}$.

The mean $\mathrm{pH}$ found in the bloom area, 8.10 (unpublished data), does not reflect any acidification of these waters compared to the oceanic mean (MILLERO; SOHN, 1992). Otherwise, the increase in the reports of T. erithraeum blooms off the Brazilian southeastern coast is noteworthy: Brandini; Moraes (1986), Gianesella-Galvão et al. (1995), Fonseca et al. (2002, unpublished), CETESB (2005, unpublished), Siqueira et al. (2006), as also in this paper.

Given the ability of Trichodesmium to assimilate organic $\mathrm{P}$ and the large area usually covered by the blooms, it may represent an important source of new $\mathrm{N}$ and the recycling of organic $\mathrm{P}$ in the southeastern Brazilian oligotrophic waters (Tropical Water) which dominate the continental shelf. Thus, efforts to understand the impact of these blooms on the trophic net of the coastal regions should be intensified.

\section{ACKNOWLEDGEMENTS}

The author wish to acknowledge their debt to the Fundação de Amparo à Pesquisa do Estado São Paulo (FAPESP), for the institutional project grant (Proc. Num.03/09932-1) as also to the crew of the R.V. Prof. W. Besnard. Melissa Carvalho wishes to thank the Conselho Nacional de Pesquisas (CNPq) for the grant conceded.

\section{REFERENCES}

AIDAR, E.; GAETA, S. A.; GIANESELLA-GALVÃO, S. M. F.; KUTNER, M. B. B.; TEIXEIRA, C. Ecossistema costeiro subtropical: nutrientes dissolvidos, fitoplâncton e clorofila-a e suas relações com as condições oceanográficas na região de Ubatuba, SP. Publ. Esp. Inst. Oceanogr., São Paulo, v. 10, p. 9-43, 1993.

AMINOT, A.; CHAUSSEPIED, M. Manuel des analyses chimiques en milieu marin. Brest, E: C.N.E.X.O., $1983.395 \mathrm{p}$.

BRANDINI, F. P.; MORAES, C. B. Composição e distribuição do fitoplâncton em áreas costeiras e oceânicas da região sueste do Brasil. Nerítica, v. 1, n. 3, p. $9-19,1986$

BRYCESON, I.; FAY, P. Nitrogen fixation in Oscillatoria (Trichodesmium) erytraea in relation to bundle formation and trichome differentiation. Mar. Biol., v. 61, p. 159-166, 1981.

CAPONE, D. G.; BURNS, J. A.; MONTOYA, J. P.; SUBRAMANIAM, A.; MAHAFFEY, C.; GUNDERSON, T.; MICHAELS, A. F.; CARPENTER, E. J. Nitrogen fixation by Trichodesmium spp.: An important source of new nitrogen to the tropical and subtropical North Atlantic Ocean. Global Biogeochem. Cy., v. 19, p. 1-17, 2005.

CAPONE, D. G.; CARPENTER, E. J. Nitrogen Fixation in the Marine Environment. Science, v. 217, p. 1140-1142, 1982.

CARPENTER, E. J. Physiology and ecology of marine planktonic Oscillatoria (Trichodesmium). Mar. Biol. Letts, v. 4, p. 69-85, 1983.

CARPENTER, E. J.; PRICE, C. C. Marine Oscillatoria (Trichodesmium): explanation for aerobic nitrogen fixation without heterocysts. Science, v. 191, p. 1278$1280,1976$.

CARPENTER, E.J.; ROMANS, K. Major role of the cyanobacterium Trichodesmium in nutrient cycling in the North Atlantic Ocean. Science, v. 254, p. 1356-1358, 1991.

CPTEC - CENTRO DE PREVISÃO DO TEMPO E ESTUDOS CLIMÁTICOS Climanálise - Boletim de monitoramento e análise climática. INPE/CPTEC, v. 21, 40 p., 2006.

GIANESELLA-GALVÃO, S. M. F.; COSTA, M. P. F.; KUTNER, M. B. B. Bloom of Oscillatoria (Trichodesmium) erythraeum (Her.) Kutz. in coastal waters of the Southwest Atlantic. Publ. Esp. do Inst. Oceanogr., São Paulo, v. 11, p. 133-140, 1995.

GRASSHOFF, K.; EHRHARDT, M.; KREMLING, K. Methods of seawater analysis. $2^{\text {nd }}$ ed. Basel: Verlag Chemie, 1983. 419 p. 
HAHN, S. T.; CAPRA, M. F. The cyanobacterium Oscillatoria erythraea: a potential source of toxin in the ciguatera food-chain. Food Addit. Contam., v. 9, n. 4, p. $351-355,1992$.

HUTCHINS, D. Ocean Acidification or $\mathrm{CO}_{2}$ fertilization? Ocean Carbon Biogeochem. News, v. 1, n. 1, p. 1-4, 2008.

HUTCHINS, D. A.; FU, F.-X.; ZHANG, Y.; WARNER, M. E.; FENG, Y.; PORTUNE, K.; BERNHARDT, P. W.; MULHOLLAND, M. R. CO2 control of Trichodesmium $\mathrm{N}_{2}$ fixation, photosynthesis, growth rates, and elemental ratios: Implications for past, present, and future ocean biogeochemistry. Limnol. Oceanogr., v. 52, n. 4, p. 1293-1304, 2007.

JEFFREY, S. W.; HUMPHREY, G. F. New spectrophotometric equations for determining chlorophylls a, b, c and c2 in higher plants, algal and natural phytoplankton. Biochem. Physiol. Planzen (BPP) Bd., v. 167 S, p. 191-194, 1975.

LEVITAN, O.; ROSENBERG, G.; SETLIK, I.; SETLIKOVA, E.; GRIGEL, J.; KLEPETAR, J.; PRASIL, O.; BERMAN-FRANK, I. Elevated $\mathrm{CO}_{2}$ enhances nitrogen fixation and growth in the marine cyanobacterium Trichodesmium. Global Change Biol. v. 13, n. 2, p. 531-538, 2007.

LEWIS, M. R.; UllOA, O.; PLATT, T. Photosyntetic action, absorption, and quantum yield spectra for a natural population of Oscillatoria in the North Atlantic. Limnol. Oceanogr., v. 33, p. 92-98, 1988.

LUGOMELA, C.; LYIMO, T. J.; BRYCESON, I.; SEMESI, A. K. Trichodesmium in coastal waters of Tanzania: diversity, seasonality, nitrogen and carbon fixation. Hydrobiologia, v. 477, p. 1-13, 2002.

MILleRO, F. J.; SOHN, M. L. Chemical Oceanography. Boca Raton, Fla : C.R.C. Press, 1992. 531 p.

NEGRI, A.P.; BUNTER, O.; JONES, B.; LLEWELLYN, L. Effects of the bloom-forming alga Trichodesmium erythraeum on the pearl oyster Pinctada maxima. Aquaculture, v. 232, p. 91-102, 2004.

POOLE, H. H.; ATKINS, W. R. G. Photo-eletric measurements of submarine illumination throughout the year. J. mar. Biol., v. 16, p. 297-324, 1929.

SALDANHA-CORREAA, F. M. P.; GIANESELLA, S. M. F.; BARRERA-ALBA, J. J. A comparison of the retention capability among three different glass-fiber filters used for chlorophyll determinations. Braz. J. Oceanogr., v. $52(3 / 4)$, p. 245-249, 2004.

SARANGI, R.K.; CHAUHAN, P.; NAYAK, S.R. Detection and monitoring of Trichodesmium blooms in the coastal waters off Saurashtra coast, India using IRS-P4 OCM data. Curr. Sci., v. 86, p. 1636-1641, 2004.
SIQUEIRA, A.; KOLM, H.E.; BRANDINI, F.P. Offshore distribution patterns of the cyanobacterium Trichodesmium erythraeum ehrenberg and associated phyto- and bacterioplankton in (on/off ?) the southern Atlantic coast (Paraná, Brazil). Braz. Arch. Biol. Technol. Mar., v. 49, p. 323-337, 2006.

SMAYDA, T. J. What is a bloom? A commentary. Limnol. Oceanogr., v. 42, p. 1132-1136, 1997.

TYRREL, T.; MARANÕN, E.; POULTON, A. J.; BOWIE, A. R.; HARBOUR, D. S.; WOODWARD, M. S. Largescale latitudinal distribution of Trichodesmium spp. in the Atlantic Ocean. J. Plankt. Res., v. 25, p. 405-416, 2003.

YENTSCH, C. M.; YENTSCH, C. S.; PERRAS, J. P. Alkaline phosphatase activity in the tropical marine bluegreen alga, Oscillatoria erythraeum ("Trichodesmium"). Limnol. Oceanogr., v. 17, p. 772-774, 1972.

ZEHR, J. P.; WATERBURY, J. B.; TURNER, P. J.; MONTOYA, J. P.; OMOREGIE, E.; STEWARD, G. F.; HANSEN, A.; KARL, D. M. Unicellular cyanobacteria fix $\mathrm{N}_{2}$ in the subtropical North Pacific Ocean. Nature, v. 412, p. 635-638, 2001.

\section{Sources of Unpublished_Material}

CETESB - COMPANHIA DE TECNOLOGIA DE SANEAMENTO AMBIENTAL. Florações de microalgas no ambiente marinho. $<$ http://www.cetesb.sp.gov.br/ Agua/praias/algas.asp.> Visited in: 3/19/2008.

FONSECA, M. L.; SILVA, M. A.; FREITAS, J. C. Ensaios preliminares da toxicidade de uma amostra de Triochodesmium erutraeum do Canal de São Sebastião, SP. In: SIMPÓSIO DE BIOLOGIA MARINHA, 17. . http://www.usp.br/cbm/novo_site/simposio/simp_xvii?re sumos/res068.html. Visited in 3/19/2008, 2002.

MIRANDA, L. B. Análise de massas de água da plataforma continental e da região oceânica adjacente: Cabo de São Tomé (RJ) a Ilha de São Sebastião (SP). Tese (Livre-Docência)- Instituto Oceanográfico da Universidade de São Paulo, São Paulo, 1982. 123 p.

(Manuscript received 05 November 2007; revised 03 March 2008; accepted 14 May 2008) 